\title{
The Influence of Variation Exercises Towards the Ability of Sepaktakraw at SMPN 17 Pekanbaru
}

\author{
Siska I ${ }^{1 *}$, Gusril ${ }^{1}$, Anton $\mathrm{K}^{1}$ \\ ${ }^{1}$ Faculty of Sports Science, Universitas Negeri Padang, Prof. Dr. Hamka Street, Padang, Indonesia \\ "Corresponding author. Email: siskaindasari75@gamail.com
}

\begin{abstract}
Based on researcher's observations, the students' ability of playing Sepaktakraw is still beyond expectation. The purpose of this research is to reveal the influence of exercise variations against the ability of sepaktakraw at SMP Negeri 17Pekanbaru. This type of research was quasi experiment. This research population was sepaktakraw extracurricular students amounted to 12 people. The instruments of the research was doing and provides opportunities for 1 minute to the students to do as many possible as counts when passing through the head. The results of this research shows that (1) there is an increase in results, (2) there is difference result between before and after exercise variations given, (3) there is an increased ability of student after being treated, (4) there is increased outcome of students' ability in doing sepaktakraw.
\end{abstract}

\section{Keywords: Exercise Variation, The Ability of Sepaktakraw}

\section{INTRODUCTION}

Sports at this time is an activity that can not be separated from human life individually or in groups. Besides that, sports are physical activities and in the formation of whole people, who are physically and mentally healthy and have a good mental attitude. Therefore, coaching in the field of sports is very closely related to life in society, nation and state.

The sepak takraw game is a game of the Malays, which grew and developed in Indonesia to the extent of extending to the Indo-Chinese peninsula. All regions claimed that sepak takraw came from his area [2]. This is logical because our brave sailors sailed across the archipelago to the land of the Indochina peninsula. In their business, they also introduced the game sepak takraw and some of them actually lived and settled in the area they visited.

Whereas in Indonesia itself Sepak takraw sports have existed since 1971 marked by the establishment of the Sepak Takraw sports organization, namely PERSERASI (Indonesian Football Association) which later changed its name in 1986 to PERSETASI (Persatuan Sepak Takraw Serikat Indonesia).

"The sepak takraw game is performed by two opposing teams, each team consists of 2 and 3 players and a reserve player, the player who performs the service is called Tekong and the two front players are called Apit kiri and Apit right. This game uses all members of the body except hand" [3]. The ball is played 3 times by returning it to the opposing field over the net. The goal of each player is to return the ball to the opposing field.

A player must master basic techniques and special techniques to play well. The basic techniques of sepak takraw include kicking, playing head, mendada, memaha, and helping [4]. While the special technique of playing sepak takraw is how to play sepak takraw including football, accepting football, feed, smash and hold (block). The more perfect mastery of each player's technique and the cooperation of each team, the better the quality of the game.

To be able to do football sila well, there are several training methods that can be used, one of which is the method of variations in training [5]. Variation of exercises is that variations of the exercises that are creatively created and applied will be able to maintain the physical and mental care of athletes practicing boredom as far as possible can be avoided [6]. Athletes always need variety in training, therefore the coach is obligatory and should create it in training. "The form of soccer practice can be done in a number of ways, including practicing soccer on its own, being joined by friends using a group of hands and balls" [7].

\section{METHOD}

The type of research in this study is the experimental method. Experiments are a way to find causal relationships (casual relationships) between two factors deliberately caused by researchers by eliminating or reducing or eliminating other disturbing factors [1]. In this study researchers used Pre Test and Post Test Design, with a pattern: $01 \mathrm{X} 02$. In this design, observations were made twice, namely before the experiment (01) and after the experiment (02). The difference between 01 and 02 is $02-$ 01 is assumed to be the effect of the experiment [8]. Population is the whole research subject. The population in this study were extracurricular students of Pangean 2 Public Middle School who participated in 12 people in sepaktakraw sports. To be more clearly seen in the following table: 
Table 1: Population of Sepak Takraw SMPN 17 Pekanbaru extracurricular students.

\begin{tabular}{|l|l|l|}
\hline No & Class & Total \\
\hline 1 & VII & 5 students \\
\hline 2 & VIII & 7 students \\
\hline & Total & 12 students \\
\hline
\end{tabular}

Samples are partially or representative of the population studied. If the subject is less than one hundred, it is better to take all of them into samples, but if the subject is more than one hundred, $10-15 \%$ or $20-25 \%$ can be taken [1]. Because the number of samples is only 12 people, the authors take everything to be sampled in this study. Determination of the sample using total sampling technique, where the entire population is used as a sample. Based on the determination of the sample above, a sample of 12 students is obtained.

\section{RESULT}

Based on the description of the data and the testing of the research hypotheses obtained the results of the study, there are effects of variations in training on the ability of football in the game of sepak takraw extracurricular students of SMP Negeri 17 Pekanbaru, which (t count) is greater than (t table). So it can be concluded that the data the researcher carefully receives. Exercise is a collection of understanding of all efforts in the process of improving achievement (including all efforts to maintain achievement). One of the exercises given is soccer practice.

Exercise is at the core of sports activation, so you need to choose various forms of exercise that have good influence. In an effort to improve the soccer skills of takraw football extracurricular students at 17 Pekanbar Public High School, it can be done using a variety of exercises, and from the results of the research it can be found that there is a significant influence. Between training variations on the ability of football, the students of the extracurricular son of sepak takraw Pekanbaru 17 High School.

Variations in the exercises represented are individual scales, soccer and self-capture, same feet, once touch, legs are twice touch, single bait is single row, bait twice touches single row, paired, moving triangle operands, in circles, operands line up.

This variation of practice enshrines the development of basic football techniques to be more improved and is expected to improve the ability of the students in the same discipline. Programmed exercises and appropriate training methods will provide a good change in your soccer skills.

Based on the results of these studies it can be said that the ability of football can be improved by using a variety of exercises. The collected data is then analyzed, while the hypotheses that will be tested are alternative hypotheses: There is Effect of Training Variations Against the Skills in the Soccer Takraw Game Students Extracurricular in the 17th Junior High School in Pekanbaru. Hypothesis testing is done to find out the results of the application of variations in training on the ability of football in the game of takraw soccer extracurricular students of the 17th week of junior high school can be seen in the following table:

Table 4: Increased Results of Variation in Exercise Against Soccer Skills and Students in Sepak Takraw Games Extracurricular New Year 17 Junior High School.

\begin{tabular}{|l|c|c|c|c|}
\hline \multicolumn{1}{|c|}{ Tes Sepak Sila } & Mean atau Nilai Rata-rata & t-Hitung & t-Tabel & Keterangan \\
\hline Pre Test & 21,16 & \multirow{2}{*}{10,43} & \multirow{2}{*}{1,728} & Signifikan \\
\hline Post Test & 25,75 & & & \\
\cline { 2 - 3 } Peningkatan Ketepatan Sepak Sila \% & 21,09 \\
\cline { 2 - 3 } &
\end{tabular}

Based on the table above, it is known that when the pre-test was conducted, it was obtained data on the ability of football skills in the sepak takraw game of extracurricular students at the 17 Pekanbaru Junior High School with Mean $=21.16$ while after variations in the exercise were applied and then tested again (post test) the mean $=25,75$. Data shows that after training with the method of variation in training is better than the test results before given a variety of exercises. Then it is known that tcount $=10.43$ while $\mathrm{t}$ table $=1.782$ and this means that Ho is rejected and Ha is accepted ie There is the Effect of Exercise Variations on Football Ability in sepak takraw games of extracurricular students of 17th State Junior High School Pekanbaru.

Then based on the analysis of data on the ability of football skills in the game of sepak takraw, extracurricular students of the 17th week of junior high school, it is known that the ability of soccer in the game of sepak takraw in extracurricular students of the 17 th week of junior high school is $21.69 \%$.

\section{CONCLUSION}

Based on the results of research and data analysis that has been done before, it can be concluded that: There is the effect of variation training on the ability of football in the extracurricular male students of Pekanbaru Public High School, the conclusion can be drawn: there is the effect of variable training on the ability of football extracurricular football students at takraw SMP Negeri 17 Pekanbaru at $2.69 \%$ with t count of 10.43 .

\section{REFERENCES}

[1] Arikunto, Suharsimi, "Prosedur Penelitian Suatu Pendekatan Praktik.," Jakarta; Rineka Cipta, pp, 23-34. 2006.

[2] Engel, Rick, "Dasar-Dasar Sepak Takraw," Bandung; Pakar Raya. 2010.

[3] Syafruddin, "Pengantar Ilmu Melatih" FIK Universitas Negeri Padang; Sukabina Press. 2012.

[4] Safri sardi, "Pengaruh variasi latihan terhadap kemampuan sepak sila siswa putera ekstrakulikuler sepak takraw SMP Negeri 2 
sentojo sentojoraya kuantan singingi," Pekanbaru;. FKIP Universitas islam riau.

[5] Iyakrus, "Permainan Sepak Takraw," Palembang. Unsri Press, pp, 45-56. 2012.

[6] Winarno, ME, "Tes Keterampilan Olahraga," FIK Universitas Negeri Malang. 2006.
[7] Usman, Husaini, "Pengantar Statistika," Yogyakarta; Bumi Aksara. 1995.

[8] Kurniawan. F, "Buku Pintar Olahraga," Jakarta; Laskar Aksara. 2012.

[9] Departemen Pendidikan Nasional, "Instrumen Pemanduan Bakat Sepak Takraw," Jakarta. 2002. 